Relations industrielles

Industrial Relations

\title{
Congress and Lobbies: Image and Reality, by Andrew M. Scott and Margaret A. Hunt, Chapel Hill, the University of North Carolina Press, 1965, 106 pages.
}

\section{André Petit}

\section{Volume 22, numéro 1, 1967}

URI : https://id.erudit.org/iderudit/027764ar

DOI : https://doi.org/10.7202/027764ar

Aller au sommaire du numéro

Éditeur(s)

Département des relations industrielles de l'Université Laval

ISSN

0034-379X (imprimé)

1703-8138 (numérique)

Découvrir la revue

Citer ce compte rendu

Petit, A. (1967). Compte rendu de [Congress and Lobbies : Image and Reality, by Andrew M. Scott and Margaret A. Hunt, Chapel Hill, the University of North Carolina Press, 1965, 106 pages.] Relations industrielles / Industrial Relations, 22(1), 137-137. https://doi.org/10.7202/027764ar

Tous droits réservés (C) Département des relations industrielles de l'Université Laval, 1967
Ce document est protégé par la loi sur le droit d'auteur. L’utilisation des services d'Érudit (y compris la reproduction) est assujettie à sa politique d'utilisation que vous pouvez consulter en ligne.

https://apropos.erudit.org/fr/usagers/politique-dutilisation/ 


\section{RECENSIONS}

Kohler on Strike, Wolter $\mathrm{H}$. Uphoff, Beacon Press, Boston, 1966. 449 pages.

Essentially, this book describes and analyses the longest lasting labor-monagement conflict in American industrial life: the two strikes at the Kohler Company near Sheboygan. Wisconsin, from 1934 to 1941 and from 1954 to 1960. Wolter Uphoff portroys the workers' reactions to the paternalistic, wellintentioned, family owned compony which expected to govern the lives of its employees and alone determine wages, define working conditions and health benefits.

We could divide this book in four (4) parts: the first one is obout the history of the Kohler village and company (chap. 1-2) followed by the description and analysis of the two strikes (chap. 3-6). The third port deals with exterior influence for settlement (chop. 7-9). In the last part we note two chapters (10-11). Chapter 10 deals with the social, economic and political factors in the strikes while chopter 11 does some evaluation.

The author has endeavored to write the story of the long and bitter controversy with sympathy and compassion, but without glossing over the most reasonable or likely explanations of what occurred and the motives behind the events which made this the longest strike in history.

This book is an effort to portray with fairness and without undue bias the dramatic events which spanned more than three decodes.

Kohler on Strike was written in the hope that the number and severity of industrial disputes could be reduced if there wos a broader understanding of the couses of industrial conflict and industrial peoce.

\section{Jean SEXTON}

\section{Congress and Lobbies: Image and Reality,} by Andrew M. Scott and Margaret $A$. Hunt, Chapel Hill, the University of North Corolino Press, 1965, 106 poges.

L'influence des groupes de pression sur la prise de décision du Congrès américain est une vérité de polichinelle. De là à croire que le Congrès est " dominé » par les groupes de pression, il n'y a qu'un pas que bien des gens ne se sont pas gênés de franchir malgré l'absence généralisée de preuves ou de données objectives sur le sujet.

Por l'usage des techniques quantitatives d'analyse, les auteurs de la présente publicotion ont voulu donner au problème un éclairage scientifique et ont tenté de dégager et d'analyser la réelle influence des a lobbies vis-à-vis le Congrès. Ils ont concentré leur ottention sur la façon dont les membres du Congrès considèrent l'action des groupes de pression et ont basé leurs conclusions sur une série d'interviews effectués durant la deuxième session du 86 e Congrès.

Parmi les 437 membres du Congrès, 40 furent choisis au hasard pour faire partie de l'échantillon. On retrouve en préface la démarche suivie por les auteurs pour justifier la représentativité de leur échantillon par ropport à l'univers. La publication contient en outre 27 tableaux qui constituent les instruments d'analyse utilisés tout au long de l'enquête selon le plan choisi par les auteurs.

Pour tous ceux qui s'intéressent à l'usage des techniques quantitatives et particulièrement pour ceux qui s'intéressent à la science politique, Congress and Lobbies sera sûrement d'un grand intérêt.

\section{André PETIT}

\section{Conditions de travail dans l'industrie cana- dienne - Working Conditions in Canadian Industry, Huitième rapport annuel, 1964. Direction de l'Economique et des Recher- ches, Ministère du Travail, Ottawa, 179 poges.}

Ce dernier rapport annuel sur les conditions de travail au Canada constitue un document important dans le cadre de cette étude en cours depuis 1957. Les différentes données, recueillies auprès des établissements de quinze employés ou plus, se rapportent aux conditions de travail suivantes: les heures de travail, les congés payés, les vacances payées, les régimes de pensions, le travail supplémentaire, le trovail par postes et le nombre d'employés auxquels s'applique un contrat collectif de travail. 